Article

\title{
Synergy between Florfenicol and Aminoglycosides against Multidrug-Resistant Escherichia coli Isolates from Livestock
}

\author{
Shukho Kim ${ }^{1}{ }^{\oplus}$, Jung Hwa Woo ${ }^{1}$, So Hyun Jun ${ }^{1}$, Dong Chan Moon ${ }^{2} \oplus$, Suk-Kyung $\operatorname{Lim}^{2}{ }^{\circledR}$ and \\ Je Chul Lee ${ }^{1, *}$ \\ 1 Department of Microbiology, School of Medicine, Kyungpook National University, Daegu 41944, Korea; \\ shukhokim@knu.ac.kr (S.K.); dasomi999@naver.com (J.H.W.); kkk016@nate.com (S.H.J.) \\ 2 Bacterial Disease Division, Animal and Plant Quarantine Agency, Gimcheon-si, \\ Gyeongsangbuk-do 39660, Korea; ansehdcks@korea.kr (D.C.M.); imsk0049@korea.kr (S.-K.L.) \\ * Correspondence: leejc@knu.ac.kr; Tel.: +82-53-420-4844
}

Received: 18 March 2020; Accepted: 13 April 2020; Published: 16 April 2020

Abstract: The increasing prevalence of antimicrobial resistance and the laborious development of novel antimicrobial agents have limited the options for effective antimicrobial therapy. The combination of previously used antimicrobial agents represents an alternative therapy for multidrug-resistant (MDR) pathogens. The objective of this study was to investigate the synergistic effect of a florfenicol (FFL)-based combination with other antimicrobial agents against MDR Escherichia coli isolates from livestock using checkerboard assays and murine infection models. The FFL/amikacin (AMK) and FFL/gentamicin (GEN) combinations showed synergy against 10/11 and 6/11 MDR E. coli isolates in vitro, respectively. The combination of FFL with aminoglycosides (AMK or GEN) exhibited a better synergistic effect against MDR E. coli isolates than the cephalothin (CEF)/GEN or FFL/CEF combinations. The combination of FFL with AMK or GEN could reduce the emergence of resistant mutants in vitro. The FFL/AMK combination showed a higher survival rate of mice infected with MDR E. coli isolates than FFL or AMK alone. In summary, the combination of FFL with aminoglycosides (AMK or GEN) is highly effective against MDR E. coli isolates both in vitro and in vivo. Our findings may contribute to the discovery of an effective combination regimen against MDR E. coli infections in veterinary medicine.

Keywords: antimicrobial agent; combination therapy; synergy; florfenicol; aminoglycosides

\section{Introduction}

The worldwide increase of antimicrobial resistance is a serious concern in both human and animal health [1]. The prevalence of multidrug-resistant (MDR) bacterial pathogens has limited the options for effective antimicrobial therapy, and development of new therapeutics active against MDR bacteria is urgently needed [2,3]. However, the development of new antimicrobial agents has not paralleled the prevalence of resistant bacteria and few novel antimicrobial agents, including derivatives from existing classes of antimicrobials, have been developed during the last decade [4-6]. In this context, the combination of previously used antimicrobial agents is an alternative therapeutic option, which can also reserve new antimicrobial agents. Combination antimicrobial therapy is used to provide a broader antibacterial spectrum, prevent the emergence of resistant bacteria, and minimize toxicity in hosts $[7,8]$. The synergy between $\beta$-lactams and aminoglycosides and between trimethoprim and sulfamethoxazole has been well defined $[9,10]$. In addition, many antimicrobial combinations are commercially available for treatment of MDR bacterial infections in veterinary medicine. 
Florfenicol (FFL), a fluorinated synthetic analog of thiamphenicol, is a broad-spectrum antimicrobial agent commonly used in veterinary medicine and aquaculture [11,12]. It binds to the 50 S ribosomal subunit and inhibits protein synthesis. Unlike chloramphenicol (CHL), FFL does not induce aplastic anemia in humans, and it is used to treat systemic bacterial infections and infectious diseases associated with respiratory pathogens in cattle, pigs, cats, dogs, and fish [13]. In Korea, the annual consumption of amphenicols in veterinary medicine gradually increased from 63.8 tons in 2010 to 99.6 tons in 2018, and the resistance rate to CHL among Escherichia coli isolates from diseased animals in 2018 ranged from $63.5 \%$ in poultry to $85.1 \%$ in pigs [14]. Moreover, resistance to CHL among E. coli isolates from healthy poultry and pigs was $44.2 \%$ and $76.7 \%$ during the same period, respectively. Aminoglycosides display bactericidal activity against most Gram-negative aerobic and facultative anaerobic bacteria. Aminoglycosides have been used extensively to treat bacterial infections in veterinary medicine due to its cost effectiveness and reliable activity against serious Gram-negative bacterial infections, but the spread of resistance, its toxicity, and relatively long withdrawal periods can limit its usage in veterinary medicine [15]. The annual consumption of aminoglycosides in veterinary medicine was 57.9 tons in 2018 in Korea, and the resistance rate to streptomycin (STR) among E. coli isolates from diseased animals in 2018 was $66.7 \%$ in poultry and $78.3 \%$ in pigs [14]. These results suggest that FFL or aminoglycosides cannot be used alone to treat $E$. coli infections in livestock. Aminoglycosides must penetrate into the cytosol of bacteria to exert their effect. The penetration of aminoglycosides into the cytosol of bacteria is enhanced by other antimicrobial agents, such as $\beta$-lactams. FFL acts as an antibacterial modulator to multiple classes of antimicrobial agents through the alteration of bacterial membrane permeability and the subsequent increase in intracellular concentrations of the antimicrobial agents used in the combination [16]. The combination of FFL with thiamphenicol showed a synergistic effect against swine Actinobacillus pleuropneumoniae and Pasteurella multocida both in vitro and in vivo $[16,17]$. The combination of FFL with oxytetracycline was also active against Pseudomonas aeruginosa isolates in vitro [16]. Based on these results, this study assessed the antimicrobial activity of FFL and other antimicrobial agents in combination against MDR E. coli isolates from livestock in vitro and in vivo.

\section{Results and Discussion}

\subsection{Combination of Amphenicols and Aminoglycosides against MDR E. coli Isolates In Vitro}

Eleven MDR E. coli isolates were tested for drug interactions between amphenicols and aminoglycosides or $\beta$-lactams using checkerboard assays (Table 1). The E. coli isolates that were previously recovered from healthy and diseased animals in Korea and showed low resistance rates to gentamicin (GEN) and amikacin (AMK) [14] were selected for a combined treatment with aminoglycosides and FFL. Resistance to STR, kanamycin (KAN), GEN, and AMK was observed in $11,8,5$, and 4 isolates, respectively (Table 1 ). Initially, the synergism between the $\beta$-lactams and aminoglycosides using checkerboard assays was assessed, but only two isolates showed synergy in the cephalothin (CEF)/GEN combination (Table 2, Table S1). With the combination of amphenicols and aminoglycosides, 10 and 6 isolates showed synergy in the FFL/AMK (Table S2) and FFL/GEN (Table S3) combinations, respectively. Synergy was observed in the CHL/GEN (Table S4) and CHL/AMK (Table S5) combinations for 6 and 8 isolates, respectively. No isolates exhibited synergy in the FFL/CEF combination (Table S6). Next, to determine whether the FFL/GEN or FFL/AMK combination could reduce the emergence of resistant bacteria compared to a single antimicrobial agent, two E. coli isolates, EC10 susceptible to FFL and GEN (Table S7) and EC15 susceptible to FFL and AMK, were cultured on a Mueller-Hinton agar plate containing single or two antimicrobial agents, and the frequency of mutant colonies was assessed after $24 \mathrm{~h}$. The E. coli EC10 isolate was from pig feces. The FFL/GEN combination reduced the emergence of mutant colonies slightly in the EC10 isolate (Table 3). However, no mutant colonies were observed in the EC15 isolate with the FFL/AMK combination. Our results 
suggest that the FFL/AMK combination is the most active against veterinary MDR E. coli isolates, and this antimicrobial combination can prevent the emergence of resistant bacteria in vitro.

Table 1. Characteristics of the E. coli isolates used in this study.

\begin{tabular}{|c|c|c|c|c|c|}
\hline Isolate No. & Animals & Samples & Isolated Year & Resistance Pattern & $\begin{array}{l}\text { Aminoglycoside-Modifying } \\
\text { Enzyme Gene }\end{array}$ \\
\hline EC1 & Pig & Feces & 2016 & $\begin{array}{l}\text { STR, AMP, AMX, CEF, NAL, CIP, } \\
\text { CHL, FFL, TET, SXT }\end{array}$ & $\operatorname{aph}\left(3^{\prime \prime}\right)-I a, \operatorname{aph}\left(3^{\prime \prime}\right)-I b$ \\
\hline EC2 & Pig & Feces & 2016 & $\begin{array}{l}\text { GEN, AMK, STR, KAN, AMP, AMX, } \\
\text { NAL, CIP, TET, SXT }\end{array}$ & $\begin{array}{l}\text { aac(3)-IVa, ant(2")-Ia, ant(3")-Ia, } \\
\operatorname{aph}\left(3^{\prime}\right)-I a\end{array}$ \\
\hline EC5 & Pig & Intestinal lesion & 2015 & $\begin{array}{l}\text { COL, GEN, STR, KAN, AMP, AMX, } \\
\text { TET, SXT }\end{array}$ & $\begin{array}{l}\operatorname{aac}(3)-I V a, \operatorname{ant}\left(3^{\prime \prime}\right)-I a, \operatorname{aph}\left(3^{\prime}\right)-I a, \\
\operatorname{aph}\left(3^{\prime \prime}\right)-I a, \operatorname{aph}\left(3^{\prime \prime}\right)-I b\end{array}$ \\
\hline EC9 & Pig & Feces & 2016 & $\begin{array}{l}\text { STR, KAN, AMP, AMX, NAL, CIP, } \\
\text { CHL, FFL, TET }\end{array}$ & $\operatorname{aph}\left(3^{\prime}\right)-I a, \operatorname{aph}\left(3^{\prime \prime}\right)-I a, a p h\left(3^{\prime \prime}\right)-I b$ \\
\hline EC14 & Chicken & Liver & 2016 & STR, AMP, AMX, TET, SXT & $\operatorname{ant}\left(3^{\prime \prime}\right)-I a$ \\
\hline EC15 & Chicken & Oviduct & 2016 & $\begin{array}{l}\text { STR, KAN, AMP, AMX, AMC, CEF, } \\
\text { NAL, CIP, CHL, TET, SXT }\end{array}$ & $\begin{array}{l}\operatorname{ant}\left(3^{\prime \prime}\right)-I a, \operatorname{aph}\left(3^{\prime}\right)-I a, \operatorname{aph}\left(3^{\prime \prime}\right)-I a, \\
\operatorname{aph}\left(3^{\prime \prime}\right)-I b\end{array}$ \\
\hline EC18 & Pig & Feces & 2016 & $\begin{array}{l}\text { AMK, STR, KAN, AMP, AMX, CEF, } \\
\text { NAL, CIP, CHL, FFL, TET, SXT }\end{array}$ & $\begin{array}{l}\operatorname{aac}\left(6^{\prime}\right)-I b, \operatorname{ant}\left(2^{\prime \prime}\right)-I a, \operatorname{ant}\left(3^{\prime \prime}\right)-I a, \\
\operatorname{aph}\left(3^{\prime}\right)-\operatorname{Ia}, \operatorname{aph}\left(3^{\prime \prime}\right)-\operatorname{Ia}, \operatorname{aph}\left(3^{\prime \prime}\right)-I b\end{array}$ \\
\hline EC19 & Pig & Intestinal lesion & 2016 & $\begin{array}{l}\text { GEN, STR, AMP, AMX, CHL, FFL, } \\
\text { TET, SXT }\end{array}$ & $\begin{array}{l}\operatorname{aac}(3)-I I a, \operatorname{ant}\left(2^{\prime \prime}\right)-I a, \operatorname{ant}\left(3^{\prime \prime}\right)-I a, \\
\operatorname{aph}\left(3^{\prime \prime}\right)-\operatorname{Ia}, \operatorname{aph}\left(3^{\prime \prime}\right)-I b\end{array}$ \\
\hline EC24 & Pig & Urinary tract & 2015 & $\begin{array}{l}\text { AMK, STR, KAN, AMP, AMX, CEF, } \\
\text { CHL, FFL, TET, SXT }\end{array}$ & $\begin{array}{l}\operatorname{ant}\left(2^{\prime \prime}\right)-\operatorname{Ia}, \operatorname{ant}\left(3^{\prime \prime}\right)-\operatorname{Ia}, \operatorname{aph}\left(3^{\prime}\right)-I a, \\
\operatorname{aph}\left(3^{\prime \prime}\right)-\operatorname{Ia}, \operatorname{aph}\left(3^{\prime \prime}\right)-I b\end{array}$ \\
\hline EC28 & Pig & Intestinal lesion & 2015 & $\begin{array}{l}\text { COL, GEN, AMK, STR, KAN, AMP, } \\
\text { AMX, CHL, FFL, TET }\end{array}$ & $\begin{array}{l}\operatorname{ant}\left(2^{\prime \prime}\right)-I a, \operatorname{ant}\left(3^{\prime \prime}\right)-I a, \operatorname{aph}\left(3^{\prime \prime}\right)-I a, \\
\operatorname{aph}\left(3^{\prime \prime}\right)-I b\end{array}$ \\
\hline EC29 & Pig & Feces & 2011 & $\begin{array}{l}\text { COL, GEN, STR, KAN, AMP, AMX, } \\
\text { NAL, CIP, CHL, FFL, TET, SXT }\end{array}$ & $\begin{array}{l}\operatorname{aac}(3)-I V a, \operatorname{ant}\left(2^{\prime \prime}\right)-I a, \operatorname{ant}\left(3^{\prime \prime}\right)-I a, \\
\operatorname{aph}\left(3^{\prime}\right)-I a, \operatorname{aph}\left(3^{\prime \prime}\right)-I a, \operatorname{aph}\left(3^{\prime \prime}\right)-I b\end{array}$ \\
\hline
\end{tabular}

Abbreviations: COL, colistin; GEN, gentamicin; AMK, amikacin; STR, streptomycin; KAN, kanamycin; AMP, ampicillin; AMX, amoxicillin; AMC, amoxicillin/clavulanic acid; CEF, cephalothin; XNL, ceftiofur; NAL, nalidixic acid; CIP, ciprofloxacin; CHL, chloramphenicol; FFL, florfenicol; TET, tetracycline; SXT, trimethoprim/sulfamethoxazole $(1: 19)$.

Table 2. In vitro inhibitory activity of different antimicrobial combinations against multidrug-resistant E. coli isolates.

\begin{tabular}{lllll}
\hline \multirow{2}{*}{$\begin{array}{c}\text { Antimicrobial } \\
\text { Combination }\end{array}$} & \multicolumn{2}{l}{ Number of Isolates $\mathbf{( \% )}$} & \\
\cline { 2 - 5 } & $\begin{array}{l}\text { Synergy } \\
\text { (FICI } \leq \mathbf{0 . 5 )}\end{array}$ & $\begin{array}{l}\text { Partial Synergy } \\
\mathbf{( 0 . 5}<\text { FICI < 1) }\end{array}$ & $\begin{array}{l}\text { Additive } \\
\text { (FICI = 1) }\end{array}$ & $\begin{array}{l}\text { Indifference } \\
(\mathbf{1}<\text { FICI < 4) }\end{array}$ \\
\hline CEF/GEN & $2(18.2)$ & $2(18.2)$ & 0 & $7(63.6)$ \\
FFL/GEN & $6(54.5)$ & $3(27.3)$ & 0 & $2(18.2)$ \\
FFL/AMK & $10(90.9)$ & $1(9.1)$ & 0 & 0 \\
CHL/GEN & $6(54.5)$ & $3(27.3)$ & 0 & $2(18.2)$ \\
CHL/AMK & $8(72.7)$ & $3(27.3)$ & 0 & 0 \\
FFL/CEF & 0 & $3(27.3)$ & $3(27.3)$ & $5(45.5)$ \\
\hline
\end{tabular}

Abbreviations: FICI, fractional inhibitory concentration index; CEF, cephalothin; GEN, gentamicin; FFL, florfenicol; AMK, amikacin; CHL, chloramphenicol.

Table 3. Mutation frequency of $E$. coli isolates with the florfenicol and aminoglycosides combination.

\begin{tabular}{|c|c|c|c|}
\hline E. coli Isolates & \multicolumn{3}{|c|}{$\begin{array}{l}\text { Frequency of Mutants Growing in Media Containing } \\
\text { Antimicrobial Agents }\end{array}$} \\
\hline \multirow{2}{*}{$\begin{array}{c}\text { EC10 } \\
\text { (MIC of FFL, } 4 \mu \mathrm{g} / \mathrm{mL} ; \mathrm{MIC} \text { of GEN, } 4 \mu \mathrm{g} / \mathrm{mL})\end{array}$} & FFL $(32 \mu \mathrm{g} / \mathrm{mL})$ & GEN (16 $\mu \mathrm{g} / \mathrm{mL})$ & $\begin{array}{c}\text { FFL }(32 \mu \mathrm{g} / \mathrm{mL}) \text { and GEN } \\
\qquad(16 \mu \mathrm{g} / \mathrm{mL})\end{array}$ \\
\hline & $2.3 \times 10^{-5}$ & $5.2 \times 10^{-5}$ & $8 \times 10^{-6}$ \\
\hline \multirow{2}{*}{$\begin{array}{c}\text { EC15 } \\
\text { (MIC of FFL, } 4 \mu \mathrm{g} / \mathrm{mL} ; \text { MIC of AMK, } 8 \mu \mathrm{g} / \mathrm{mL} \text { ) }\end{array}$} & FFL $(32 \mu \mathrm{g} / \mathrm{mL})$ & AMK $(64 \mu \mathrm{g} / \mathrm{mL})$ & $\begin{array}{l}\text { FFL }(32 \mu \mathrm{g} / \mathrm{mL}) \text { and } \\
\text { AMK }(64 \mu \mathrm{g} / \mathrm{mL})\end{array}$ \\
\hline & $2 \times 10^{-7}$ & $1.4 \times 10^{-6}$ & 0 \\
\hline
\end{tabular}




\subsection{Combination of FFL and Aminoglycosides against MDR E. coli Isolates In Vivo}

To determine whether the combination of FFL with aminoglycosides (AMK or GEN) was active against MDR E. coli isolates in vivo, mice were infected with E. coli intraperitoneally and then antimicrobials were injected intramuscularly. The three E. coli isolates in each group that showed synergy in the checkerboard assays, EC2, EC5, and EC9 for the combination of FFL/AMK and EC1, EC18, and EC29 for the combination of FFL/GEN, were selected for the combination therapy. Death was observed within $48 \mathrm{~h}$ in all the control mice treated with phosphate-buffered saline (PBS). The mice that were infected with either of the three E. coli isolates and then treated with the FFL/AMK combination exhibited a higher survival rate $(60 \%-100 \%)$ than the infected animals treated with FFL $(0 \%-80 \%)$ or AMK alone (20\%-80\%) (Figure 1A). The FFL/GEN combination showed the same survival rate (100\%) of mice infected with two E. coli isolates, EC18 and EC29, compared to GEN alone (100\%) (Figure 1B). Treatment of FFL alone reduced the survival rate $(20 \%-80 \%)$ in mice infected with six E. coli isolates than with the combination of FFL/AMK (60\%-100\%) or FFL/GEN (80\%-100\%). These results suggest that the FFL/AMK combination is more effective in mice infected with the MDR E. coli isolates than FFL or AMK alone.
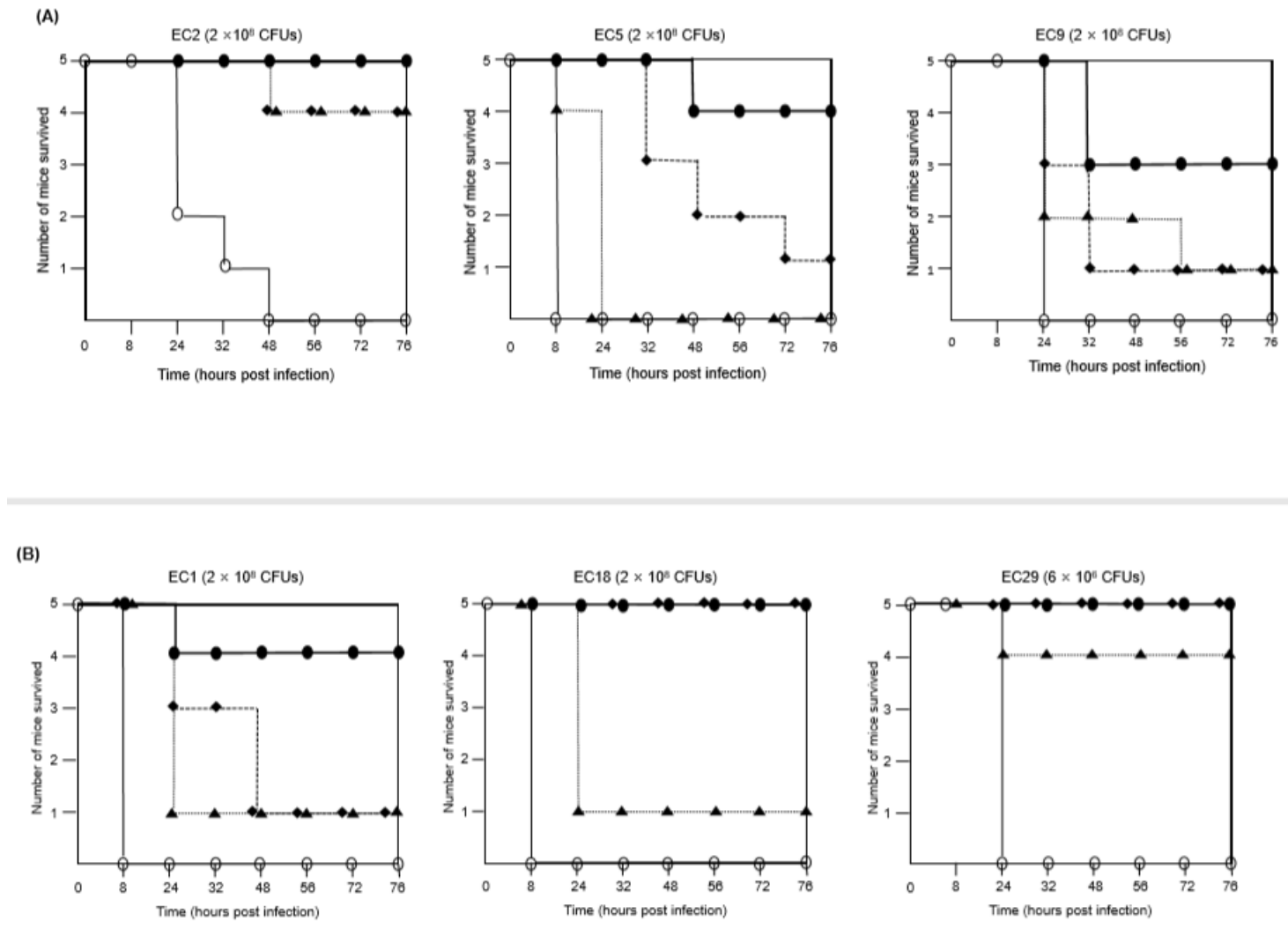

Figure 1. Treatment of mice infected with E. coli isolates. Mice were infected with E. coli isolates intraperitoneally. Bacterial inoculum size is indicated in parentheses. After $30 \mathrm{~min}$, the mice received antimicrobial agents intramuscularly. (A) Mice infected with E. coli isolates (EC2, EC5, and EC9) were treated with PBS $(\bigcirc)$, FFL $(\boldsymbol{\Lambda}, 20 \mathrm{mg} / \mathrm{kg}), \operatorname{AMK}(\diamond, 10 \mathrm{mg} / \mathrm{kg})$, or FFL $(20 \mathrm{mg} / \mathrm{kg}) / \operatorname{AMK}(\bullet, 10 \mathrm{mg} / \mathrm{kg})$. (B) Mice infected with E. coli isolates (EC1, EC18, and EC29) were treated with PBS $(\bigcirc)$, FFL $(\mathbf{\Delta}$, $20 \mathrm{mg} / \mathrm{kg}), \mathrm{GEN}(\bullet, 20 \mathrm{mg} / \mathrm{kg})$, or FFL $(20 \mathrm{mg} / \mathrm{kg}) / \mathrm{GEN}(\bullet, 20 \mathrm{mg} / \mathrm{kg})$.

The emergence and spread of the E. coli isolates resistant to previously used antimicrobial agents, including veterinary, critically important antimicrobials, have forced veterinarians to use combinations of these antimicrobial agents. In vitro synergy tests can provide a guide for combination therapies, but it is important to determine the synergistic activity of these combinations in vivo. In Korea, amoxicillin/clavulanic acid (AMC) was highly active against E. coli isolates from diseased animals 
in 2018 , with a resistant rate of $4.2 \%$, whereas the same set of E. coli isolates was highly resistant to trimethoprim/sulfamethoxazole (53.5\%) [14]. In this study, all isolates were resistant to amoxicillin (AMX) (MICs $\geq 512 \mu \mathrm{g} / \mathrm{mL})$, but resistance to AMC was observed in one E. coli isolate. The current study assessed the synergy between $\beta$-lactams and aminoglycosides in combination against MDR E. coli isolates. The combination of CEF/GEN showed synergy in two isolates. It is necessary to develop new antimicrobial combination regimens for treatment of MDR E. coli infections in veterinary medicine. Based on the action mechanisms of FFL as an initial antibacterial modulator to multiple classes of antimicrobials [16], the current study assessed FFL-based combinations with aminoglycosides against MDR E. coli isolates. Checkerboard assays revealed that the combination of FFL with aminoglycosides was more active against MDR E. coli isolates than CEF/GEN or FFL/CEF in vitro. The FFL/AMK combination was the most active against MDR E. coli isolates and could prevent the emergence of resistant mutants. FFL was more active than $\mathrm{CHL}$ in the combination with AMK. The combination therapy with FFL/AMK or FFL/GEN was also promising against MDR E. coli isolates in vivo. Although the combination of FFL/GEN exhibited the same survival rates of mice compared to GEN alone in EC18 and EC29 isolates, the combination of FFL/GEN may reduce the emergence of resistant mutants. We tested representative MDR E. coli isolates from diseased livestock in Korea. It would be of interest to confirm the synergy between FFL and aminoglycosides by conducting studies with different clones or MDR E. coli strains originating from different geographical areas. The pharmacokinetics and pharmacodynamics of the FFL/AMK or FFL/GEN combinations should be also studied for clinical use, because the drug interactions between two antimicrobial agents and bacteria-host interactions cannot be mimicked utilizing in vitro models. In summary, the synergy between FFL and aminoglycosides against MDR E. coli isolates from livestock was demonstrated both in vitro and in vivo for the first time. Because MDR E. coli infections represent a major therapeutic challenge in veterinary medicine, our findings may contribute to the discovery of an effective combination regimen against veterinary MDR E. coli infections.

\section{Materials and Methods}

\subsection{Bacterial Strains}

A total of 12 MDR E. coli isolates were used in this study (Table 1 and Table S7). MDR E. coli isolates that were resistant to 5 or more different classes of antimicrobial agents were selected from a collection of $E$. coli isolates from fecal samples or tissue lesions of diseased animals at the diagnostic laboratory of the Bacterial Disease Division, Korea Animal and Plant Quarantine Agency, between 2011 and 2016. Twelve representative MDR E. coli isolates were then selected based on the antimicrobial resistance pattern, minimum inhibitory concentrations (MICs) of antimicrobial agents, carriage of aminoglycoside-modifying enzyme genes, geographical location of the farms, clinical samples, and source of animals. Eleven E. coli isolates were used to determine the synergism between the antimicrobial agents (Table 1). Two E. coli isolates, EC10 and EC15, were used to determine the mutation frequency in a combination of FFL and aminoglycosides. Nine and two isolates were from pigs and chicken, respectively. All E. coli isolates were obtained from the Korea Veterinary Culture Collection (KVCC).

\subsection{Antimicrobial Susceptibility Testing}

The MICs of 13 antimicrobial agents were determined by the Sensititre susceptibility system using the KRNV4F Sensititre panel (Trek Diagnostic Systems) according to the manufacturer's instructions. The MICs of AMK, KAN, and AMX were determined by the broth microdilution method according to the guidelines of the Clinical Laboratory Standards Institute (CLSI) [18]. E. coli American Type Culture Collection (ATCC) 25922 and P. aeruginosa ATCC 27853 were used as quality control strains. Interpretation of antimicrobial susceptibility was based on the guidelines of the CLSI when the MICs of the antimicrobial agents against the quality control strains were within the acceptable ranges. 
The breakpoints of ceftiofur, FFL, and STR were determined using the guidelines of the National Antimicrobial Resistance Monitoring System in Korea [19].

\subsection{Polymerase Chain Reaction (PCR) Analysis of Aminoglycoside-Modifying Enzyme Genes}

PCR was performed in a $20 \mu \mathrm{L}$ volume containing $2 \mu \mathrm{L}$ of boiled bacterial suspensions, $20 \mathrm{pM}$ of each primer, $250 \mu \mathrm{M}$ dNTPs, $10 \mathrm{mM}$ Tris- $\mathrm{HCl}(\mathrm{pH} 8.3), 50 \mathrm{mM} \mathrm{KCl}, 2.5 \mathrm{mM} \mathrm{MgCl}$, and $1.5 \mathrm{U}$ of Taq DNA polymerase (Bioneer, Daejeon, Republic of Korea). Genes coding for aminoglycoside-modifying enzymes were amplified using primers specific for $a a c\left(6^{\prime}\right)-I b$, aac(3)-IIa, aac(3)-IVa, ant(2")-Ia, ant( (3")-Ia, $a p h\left(3^{\prime}\right)-I a, a p h\left(3^{\prime \prime}\right)-I a$, and $a p h\left(3^{\prime \prime}\right)-I b$ [20]. PCR conditions were followed as previously described [20].

\subsection{Checkerboard Assay}

In vitro synergy testing was performed using the checkerboard assay in a 96-well microplate. Preparation of bacteria and antimicrobial agents for the assay was conducted according to the CLSI guidelines [18]. In brief, bacteria (approximately $5 \times 10^{5}$ colony forming units (CFUs) $/ \mathrm{mL}$ ) were prepared in cation-adjusted Mueller-Hinton broth (Difco) and inoculated in a 96-well microplate $(100 \mu \mathrm{L} /$ well). Two antimicrobial agents in each well were added and diluted two-fold, serially, horizontally and vertically. The fractional inhibitory concentration index (FICI) value was quantified using the following equation: $\mathrm{FICI}=\mathrm{FIC}_{\mathrm{A}}+\mathrm{FIC}_{\mathrm{B}}=(\mathrm{MIC}$ of drug $\mathrm{A}$ in combination/MIC of drug A alone) + (MIC of drug B in combination/MIC of drug B alone). Drug interaction was classified as synergy, partial synergy, additivity, indifference, or antagonism [21,22]. Synergy, partial synergy, additivity, indifference, and antagonism were defined as FICI $\leq 0.5,0.5<\mathrm{FICI}<1, \mathrm{FICI}=1,1<\mathrm{FICI}<4$, and FICI $\geq 4$, respectively.

\subsection{Mutation Frequency of E. coli Isolates}

The mutation frequency was assessed from two E. coli isolates (EC10 and EC15) by exposing the bacteria to FFL, GEN, AMK, FFL/GEN, or FFL/AMK. E. coli EC10 and EC15 isolates were susceptible to FFL, GEN, and AMK. Bacteria ( $\left.10^{9} \mathrm{CFUs}\right)$ were spread onto Mueller-Hinton agar plates containing FFL $(32 \mu \mathrm{g} / \mathrm{mL})$, GEN $(16 \mu \mathrm{g} / \mathrm{mL})$, AMK $(64 \mu \mathrm{g} / \mathrm{mL})$, FFL $(32 \mu \mathrm{g} / \mathrm{mL}) / \mathrm{GEN}(16 \mu \mathrm{g} / \mathrm{mL})$, and FFL $(32 \mu \mathrm{g} / \mathrm{mL}) / \mathrm{AMK}(64 \mu \mathrm{g} / \mathrm{mL})$. The cultures were incubated at $37^{\circ} \mathrm{C}$ overnight and then colonies were counted.

\subsection{In Vivo Animal Experiments}

Five-week-old female BALB/c mice (18-20 g) were purchased from Hyochang Science (Daegu, Korea) and housed under specific pathogen-free conditions. The animals were housed with five mice per cage in a laminar airflow room maintained at a temperature of $24 \pm 2{ }^{\circ} \mathrm{C}$, with a relative humidity of $55 \% \pm 5 \%$ throughout the study. Mice were maintained for at least five days after caging and then six-week-old mice were used for experiments. The bacterial inoculum was prepared from an overnight culture of E. coli on blood agar plates and resuspended in PBS. The fifty percent lethal dose $\left(\mathrm{LD}_{50}\right)$ was determined by inoculating groups of six mice intraperitoneally with serial 10-fold dilutions of E. coli isolates (https://www.aatbio.com/tools/ld50-calculator). The $5 \times \mathrm{LD}_{50}$ CFUs of bacteria $\left(6 \times 10^{6} \mathrm{CFUs} / 500 \mu \mathrm{L}\right.$ for EC29 and $2 \times 10^{8} \mathrm{CFUs} / 500 \mu \mathrm{L}$ for EC1, EC2, EC5, EC9, and EC18) were administered intraperitoneally. Thirty minutes after bacterial injection, $50 \mu \mathrm{L}$ of FFL $(20 \mathrm{mg} / \mathrm{kg})$, GEN $(20 \mathrm{mg} / \mathrm{kg})$, or AMK $(10 \mathrm{mg} / \mathrm{kg})$ was injected intramuscularly into the right thigh for monotherapy, and $50 \mu \mathrm{L}$ of FFL $(20 \mathrm{mg} / \mathrm{kg})$ and $50 \mu \mathrm{L}$ of aminoglycosides $(20 \mathrm{mg} / \mathrm{kg}$ for GEN or $10 \mathrm{mg} / \mathrm{kg}$ for AMK) were injected into the left and right thigh, respectively, for combination therapy [23-27]. Control animals received PBS injection in both thighs. Mortality was monitored for $76 \mathrm{~h}$. All animal experiments were approved by Institutional Animal Care and Use Committee of Kyungpook National University (2018-0138). 
Supplementary Materials: The following are available online at http://www.mdpi.com/2079-6382/9/4/185/s1, Table S1: In vitro synergy between cephalothin and gentamicin in combination against 11 multidrug-resistant E. coli isolates. Table S2: In vitro synergy between florfenicol and amikacin in combination against 11 multidrug-resistant E. coli isolates. Table S3: In vitro synergy between florfenicol and gentamicin in combination against 11 multidrug-resistant $E$. coli isolates. Table S4: In vitro synergy between chloramphenicol and gentamicin in combination against 11 multidrug-resistant $E$. coli isolates. Table S5: In vitro synergy between chloramphenicol and amikacin in combination against 11 multidrug-resistant $E$. coli isolates. Table S6: In vitro synergy between florfenicol and cephalothin in combination against 11 multidrug-resistant E. coli isolates. Table S7: Minimum inhibitory concentrations (MICs) of 16 antimicrobial agents against $12 \mathrm{E}$. coli isolates used in this study.

Author Contributions: D.C.M., S.-K.L. and J.C.L. conceived the ideas and designed the study; S.K., J.H.W. and S.H.J. carried out the experiments; S.K., D.C.M. and J.C.L. analyzed the data; S.K. and J.C.L. wrote the manuscript. All authors have read and agreed to the published version of the manuscript.

Funding: This study was supported by a grant from the Animal and Plant Quarantine Agency, Ministry of Agriculture, Food, and Rural Affairs, Republic of Korea (Z-1543081-2017-18-01).

Conflicts of Interest: The authors declare no conflicts of interest.

\section{References}

1. Poirel, L.; Madec, J.-Y.; Lupo, A.; Schink, A.-K.; Kieffer, N.; Nordmann, P.; Schwarz, S. Antimicrobial Resistance in Escherichia coli. Microbiol. Spectr. 2018, 6, 289-316. [CrossRef]

2. Frieri, M.; Kumar, K.; Boutin, A. Antibiotic resistance. J. Infect. Public Health 2017, 10, 369-378. [CrossRef]

3. Pogue, J.M.; Kaye, K.; Cohen, D.; Marchaim, D. Appropriate antimicrobial therapy in the era of multidrug-resistant human pathogens. Clin. Microbiol. Infect. 2015, 21, 302-312. [CrossRef]

4. Cock, I.; Cheesman, M.J.; Ilanko, A.; Blonk, B. Developing new antimicrobial therapies: Are synergistic combinations of plant extracts/compounds with conventional antibiotics the solution? Pharmacogn. Rev. 2017, 11, 57-72. [CrossRef] [PubMed]

5. Dokla, E.M.E.; Abutaleb, N.S.; Milik, S.; Li, D.; El-Baz, K.; Shalaby, M.-A.W.; Al-Karaki, R.; Nasr, M.; Klein, C.D.; Abouzid, K.A.; et al. Development of benzimidazole-based derivatives as antimicrobial agents and their synergistic effect with colistin against gram-negative bacteria. Eur. J. Med. Chem. 2020, 186, 111850. [CrossRef] [PubMed]

6. Kaur, H.; Narasimhan, B. Antimicrobial Activity of Diazenyl Derivatives: An Update. Curr. Top. Med. Chem. 2018, 18, 3-21. [CrossRef] [PubMed]

7. Pletz, M.W.; Hagel, S.; Forstner, C. Who benefits from antimicrobial combination therapy? Lancet Infect. Dis. 2017, 17, 677-678. [CrossRef]

8. A Hill, J.; Cowen, L.E. Using combination therapy to thwart drug resistance. Futur. Microbiol. 2015, 10, 1719-1726. [CrossRef]

9. Davis, B.D. Bactericidal synergism between beta-lactams and aminoglycosides: Mechanism and possible therapeutic implications. Rev. Infect. Dis. 1982, 4, 237-245. [CrossRef]

10. Minato, Y.; Dawadi, S.; Kordus, S.L.; Sivanandam, A.; Aldrich, C.C.; Baughn, A.D. Mutual potentiation drives synergy between trimethoprim and sulfamethoxazole. Nat. Commun. 2018, 9, 1003. [CrossRef]

11. Assane, I.M.; Gozi, K.S.; Valladão, G.M.R.; Pilarski, F. Combination of antimicrobials as an approach to reduce their application in aquaculture: Emphasis on the use of thiamphenicol/florfenicol against Aeromonas hydrophila. Aquaculture 2019, 507, 238-245. [CrossRef]

12. White, D.G.; Hudson, C.; Maurer, J.J.; Ayers, S.; Zhao, S.; Lee, M.D.; Bolton, L.; Foley, T.; Sherwood, J. Characterization of Chloramphenicol and Florfenicol Resistance in Escherichia coli Associated with Bovine Diarrhea. J. Clin. Microbiol. 2000, 38, 4593-4598. [CrossRef] [PubMed]

13. Ferreira, C.S.G.; Nunes, B.; Almeida, J.; Guilhermino, L. Acute toxicity of oxytetracycline and florfenicol to the microalgae Tetraselmis chuii and to the crustacean Artemia parthenogenetica. Ecotoxicol. Environ. Saf. 2007, 67, 452-458. [CrossRef] [PubMed]

14. Animal and Plant Quarantine Agency (APQA). Antimicrobial Use and Antimicrobial Resistance Monitoring in Animals and Animal Products; APQA: Gimcheon, Korea, 2019.

15. Dowling, P.M. Aminoglycosides. In Antimicrobial Therapy in Veterinary Medicine, 4th ed.; Giguère, S., Prescott, J.F., Baggot, J.D., Walker, R.D., Dowling, P.M., Eds.; Wiley Blackwell Publishing: Ames, IA, USA, 2017; pp. 207-229. 
16. Wei, C.-F.; Shien, J.-H.; Chang, S.-K.; Chou, C.-C. Florfenicol As a Modulator Enhancing Antimicrobial Activity: Example Using Combination with Thiamphenicol against Pasteurella multocida. Front. Microbiol. 2016, 7, 465. [CrossRef] [PubMed]

17. Rattanapanadda, P.; Kuo, H.-C.; Vickroy, T.W.; Sung, C.-H.; Rairat, T.; Lin, T.-L.; Yeh, S.-Y.; Chou, C.-C. In vitro and in vivo Synergistic Effects of Florfenicol and Thiamphenicol in Combination Against Swine Actinobacillus pleuropneumoniae and Pasteurella multocida. Front. Microbiol. 2019, 10, 2430. [CrossRef]

18. Clinical and Laboratory Standards Institute (CLSI). Performance Standards for Antimicrobial Susceptibility Testing: Twenty-seventh Informational Supplement M100-S28; CLSI: Wayne, PA, USA, 2018.

19. Animal and Plant Quarantine Agency (APQA). National Antimicrobial Resistance Monitoring System in Korea; APQA: Gimcheon, Korea, 2014.

20. Belaynehe, K.M.; Shin, S.W.; Hong-Tae, P.; Yoo, H.S. Occurrence of aminoglycoside-modifying enzymes among isolates of Escherichia coli exhibiting high levels of aminoglycoside resistance isolated from Korean cattle farms. FEMS Microbiol. Lett. 2017, 364, 129. [CrossRef]

21. Johnson, D.M.; Fritsche, T.R.; Sader, H.S.; Jones, R.N. Evaluation of dalbavancin in combination with nine antimicrobial agents to detect enhanced or antagonistic interactions. Int. J. Antimicrob. Agents 2006, 27, 557-560. [CrossRef]

22. Dawis, M.A.; Isenberg, H.D.; France, K.A.; Jenkins, S.G. In vitro activity of gatifloxacin alone and in combination with cefepime, meropenem, piperacillin and gentamicin against multidrug-resistant organisms. J. Antimicrob. Chemother. 2003, 51, 1203-1211. [CrossRef]

23. Yang, F.; Yang, F.; Kong, T.; Wang, G.; Bai, D.; Liu, B. Pharmacokinetics of florfenicol and its metabolite florfenicol amine in crucian carp (Carassius auratus) at three temperatures after one single intramuscular injection. J. Veter- Pharmacol. Ther. 2018, 41, 739-745. [CrossRef]

24. Varzi, H.N.; Esmailzadeh, S.; Morovvati, H.; Avizeh, R.; Shahriari, A.; Givi, M.E. Effect of silymarin and vitamin E on gentamicin-induced nephrotoxicity in dogs. J. Veter Pharmacol. Ther. 2007, 30, 477-481. [CrossRef]

25. Agrawal, A.K.; Singh, S.D.; Jayachandran, C. Effect of fever on pharmacokinetics and dosage regimen of intramuscularly administered amikacin in goats. J. Veter Sci. 2001, 2, 91-96. [CrossRef]

26. Baggot, J.D.; Ling, G.V.; Chatfield, R.C. Clinical pharmacokinetics of amikacin in dogs. Am. J. Veter Res. 1985, 46, 1793-1796.

27. Thadepalli, H.; Hajji, M.; Perumal, V.K.; Chuah, S.K.; Gollapudi, S. Evaluation of temafloxacin in a rat model of intra-abdominal abscess. J. Antimicrob. Chemother. 1992, 29, 687-692. [CrossRef] [PubMed] 